\title{
Front Matter: Volume 7429
}

, "Front Matter: Volume 7429," Proc. SPIE 7429, Novel Optical Systems Design and Optimization XII, 742901 (17 September 2009); doi:

$10.1117 / 12.846875$

SPIE Event: SPIE Optical Engineering + Applications, 2009, San Diego, California, SPIE. United States 


\title{
PROCEEDINGS OF SPIE
}

\section{Novel Optical Systems Design and Optimization XII}

\author{
R. John Koshel \\ G. Groot Gregory \\ Editors
}

3-4 August 2009

San Diego, California, United States

Sponsored and Published by

SPIE 
The papers included in this volume were part of the technical conference cited on the cover and title page. Papers were selected and subject to review by the editors and conference program committee. Some conference presentations may not be available for publication. The papers published in these proceedings reflect the work and thoughts of the authors and are published herein as submitted. The publisher is not responsible for the validity of the information or for any outcomes resulting from reliance thereon.

Please use the following format to cite material from this book:

Author(s), "Title of Paper," in Novel Optical Systems Design and Optimization XII, edited by R. John Koshel, G. Groot Gregory, Proceedings of SPIE Vol. 7429 (SPIE, Bellingham, WA, 2009) Article CID Number.

ISSN 0277-786X

ISBN 9780819477194

Published by

SPIE

P.O. Box 10, Bellingham, Washington 98227-0010 USA

Telephone +1 3606763290 (Pacific Time) · Fax +1 3606471445

SPIE.org

Copyright (C) 2009, Society of Photo-Optical Instrumentation Engineers

Copying of material in this book for internal or personal use, or for the internal or personal use of specific clients, beyond the fair use provisions granted by the U.S. Copyright Law is authorized by SPIE subject to payment of copying fees. The Transactional Reporting Service base fee for this volume is $\$ 18.00$ per article (or portion thereof), which should be paid directly to the Copyright Clearance Center (CCC), 222 Rosewood Drive, Danvers, MA 01923. Payment may also be made electronically through CCC Online at copyright.com. Other copying for republication, resale, advertising or promotion, or any form of systematic or multiple reproduction of any material in this book is prohibited except with permission in writing from the publisher. The CCC fee code is 0277-786X/09/ $\$ 18.00$.

Printed in the United States of America.

Publication of record for individual papers is online in the SPIE Digital Library.

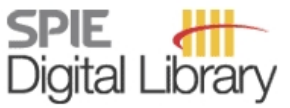

SPIEDigitalLibrary.org

Paper Numbering: Proceedings of SPIE follow an e-First publication model, with papers published first online and then in print and on CD-ROM. Papers are published as they are submitted and meet publication criteria. A unique, consistent, permanent citation identifier (CID) number is assigned to each article at the time of the first publication. Utilization of CIDs allows articles to be fully citable as soon they are published online, and connects the same identifier to all online, print, and electronic versions of the publication. SPIE uses a six-digit CID article numbering system in which:

- The first four digits correspond to the SPIE volume number.

- The last two digits indicate publication order within the volume using a Base 36 numbering system employing both numerals and letters. These two-number sets start with 00, 01, 02, 03, 04, $05,06,07,08,09,0 A, 0 B \ldots 0 Z$, followed by 10-1Z, 20-2Z, etc.

The CID number appears on each page of the manuscript. The complete citation is used on the first page, and an abbreviated version on subsequent pages. Numbers in the index correspond to the last two digits of the six-digit CID number. 


\title{
Contents
}

\author{
vii Conference Committee \\ ix Introduction
}

\section{SESSION 1 DESIGN IN COMPUTED IMAGING I}

742902 Low-complexity digital filter geometry for spherical coded imaging systems [7429-01] G. Feng, Ricoh Innovations, Inc. (United States); M. Shoaib, Princeton Univ. (United States); M. D. Robinson, Ricoh Innovations, Inc. (United States)

742903 Optimality of pupil-phase profiles for increasing the defocus tolerance of hybrid digital-optical imaging systems (Invited Paper) [7429-02]

T. Vettenburg, Heriot-Watt Univ. (United Kingdom); A. Wood, N. Bustin, Qioptiq Ltd. (United Kingdom); A. R. Harvey, Heriot-Watt Univ. (United Kingdom)

742904 Depth of field extension in a low power microscope objective [7429-03]

P. Mouroulis, B. E. van Gorp, H. A. Bender, E. E. Bloemhof, J. Nichols, S. Douglas, Jet Propulsion Lab. (United States)

742905 Depth perception with a rotationally symmetric coded camera [7429-04]

C.-C. Chang, National Central Univ. (Taiwan) and Industrial Technology Research Institute (Taiwan); Y.-L. Chen, C.-W. Chang, Industrial Technology Research Institute (Taiwan);

C.-C. Lee, National Central Univ. (Taiwan)

742906 Infrared image guidance for ground vehicle based on fast wavelet image focusing and tracking [7429-05]

A. Akiyama, Kanazawa Technical College (Japan); N. Kobayashi, Kanazawa Institute of Technology (Japan); E. Mutoh, Kawasaki Heavy Industries, Ltd. (Japan); H. Kumagai, Tamagawa Seiki Co., Ltd. (Japan); H. Yamada, Kanazawa Technical College (Japan); H. Ishii, Nihon Univ. (Japan)

\section{SESSION 2 ILLUMINATION}

742907 Chromatic perception of non-invasive lighting of cave paintings [7429-06]

J. Zoido, D. Vazquez, A. Álvarez, E. Bernabeu, Univ. Complutense de Madrid (Spain); Á. García, Univ. Politécnica de Madrid (Spain); J. A. Herraez, M. del Egido, Instituto del Patrimonio Historico Español (Spain)

742908 Efficient measurement of large light source near-field color and luminance distributions for optical design and simulation (Invited Paper) [7429-07]

H. Kostal, D. Kreysar, R. Rykowski, Radiant Imaging, Inc. (United States)

742909 A beam splitter of natural light guiding system based on dichroic prism for ecological illumination [7429-08]

Y.-C. Li, Y.-Y. Chen, A. J.-W. Whang, National Taiwan Univ. of Science and Technology (Taiwan) 
7429 OA Design and optimization of dot pattern in illumination lightpipe of natural light guiding system [7429-09]

Z.-Y. Lee, Y.-Y. Chen, A. J.-W. Whang, National Taiwan Univ. of Science and Technology (Taiwan)

\section{SESSION 3 MODELING}

7429 OC Overview of the SMS design method applied to imaging optics [7429-14]

J. C. Miñano, P. Benítez, W. Lin, Univ. Politécnica de Madrid (Spain); F. Muñoz, LPI (United States); J. Infante, A. Santamaría, Univ. Politécnica de Madrid (Spain)

7429 OD Raytrace assisted analytical formulation of Fresnel lens transmission efficiency [7429-12] A. Davis, Reflexite (United States)

7429 OE Design, analysis, and fabrication of a really bad lens [7429-13]

A. W. Greynolds, Ruda-Cardinal Inc. (United States)

7429 OF Optimization of optics with micro diffractive optical element via a hybrid Taguchi genetic algorithm [7429-11]

T.-K. Liu, Y.-C. Fang, B.-W. Wu, National Kaohsiung First Univ. of Science and Technology (Taiwan); J. MacDonald, The Univ. of Reading (United Kingdom); J.-H. Chou, National Kaohsiung First Univ. of Science and Technology (Taiwan); C.-M. Tsai, Kun Shan Univ. (Taiwan); H.-C. Lin, W. T. Lin, National Kaohsiung First Univ. of Science and Technology (Taiwan)

7429 OG Flight miniature Risley prism mechanism [7429-16]

C. S. Clark, S. Gentile, Lockheed Martin Advanced Technology Ctr. (United States)

$7429 \mathrm{OH} \quad$ Collection optics for imaging spectroscopy of an electric arc shock tube [7429-17] R. B. Greenberg, ELORET Corp. (United States); B. A. Cruden, J. H. Grinstead, NASA Ames Research Ctr. (United States); D. Yeung, Sierra Lobo Corp. (United States)

7429 Ol Laser despeckled image [7429-18]

M. Tilleman, Elbit Systems of America, Inc. (United States)

7429 0J Speckle interferometric sensor to measure low-amplitude high frequency ocular microtremor (OMT) [7429-19]

J. P. Ryle, Univ. College Dublin (Ireland) and SFI Strategic Research Ctr. in Solar Energy Conversion (Ireland); M. Al-Kalbani, Mercer's Institute for Research on Ageing (Ireland) and St. James's Hospital (Ireland); U. Gopinathan, Instrument Research and Development Establishment (India); G. Boyle, D. Coakley, Mercer's Institute for Research on Ageing (Ireland) and St. James's Hospital (Ireland); J. T. Sheridan, Univ. College Dublin (Ireland) and SFI Strategic Research Ctr. in Solar Energy Conversion (Ireland)

7429 OK Analysis of required shape of flexible sensor for different lens focus [7429-20]

D. Shaw, S.-P. Cuo, C. W. Lin, National Tsing Hua Univ. (Taiwan) 
7429 OL Ray tracing, wavefronts, and caustics: use of Shack-Hartmann wavefront sensor for analyzing light propagation [7429-21]

S. Bosch, S. Vallmitjana, C. Ferran, Univ. de Barcelona (Spain)

7429 OM Spherical coded imagers: improving lens speed, depth-of-field, and manufacturing yield through enhanced spherical aberration and compensating image processing (Invited Paper) [7429-22]

M. D. Robinson, G. Feng, D. G. Stork, Ricoh Innovations, Inc. (United States)

7429 ON A technique to remove image artefacts in optical systems with wavefront coding [7429-23] M. Demenikov, A. R. Harvey, Heriot-Watt Univ. (United Kingdom)

SESSION 6 EDUCATION

7429 OP Case study findings of PHOTON problem-based learning (PBL) with high school photonics outreach programs [7429-25]

J. Hilliard-Clark, P. Gilchrist, S. Allgood, North Carolina State Univ. (United States)

$7429 \mathrm{OQ}$ Restarting a high school photonics program [7429-26]

B. K. Belcher, Plainfield High School (United States); J. Donnelly, Three Rivers Community College (United States)

7429 OR Teaching photonics technology students to think: methods [7429-27]

G. B. Beasley, J. Yeatman, Central Carolina Community College (United States)

7429 OS An optics first year experience course for community college students [7429-28]

J. Donnelly, Three Rivers Community College (United States)

\section{POSTER SESSION}

7429 OT A spherical catadioptric telescope system based on Cooke corrector group [7429-29] J. Zhang, Changchun Institute of Optics, Fine Mechanics and Physics (China) and Graduate School of Chinese Academy of Sciences (China); Y. Kang, W. Liu, Changchun Institute of Optics, Fine Mechanics and Physics (China)

7429 OW Depth of field estimation: theory, experiment, and application [7429-32]

R. H. Abd El-Maksoud, L. Wang, J. M. Sasian, College of Optical Sciences, The Univ. of Arizona (United States); V. S. Valencia, College of Optical Sciences, The Univ. of Arizona (United States) and Authenti-Corp (United States)

7429 OX Optical design of endoscopic shape-tracker using quantum dots embedded in fiber bundles [7429-34]

J. Eisenstein, R. Gavalis, P. Y. Wong, C. G. L. Cao, Tufts Univ. (United States)

7429 OZ Development of tissue multi-slice laser reflectance imaging system [7429-36]

J. Indumathi, M. Singh, Vellore Institute of Technology Univ. (India) 
742910 Structural design of optically compensated zoom lenses using genetic algorithm [7429-37] S. Pal, L. N. Hazra, Univ. of Calcutta (India)

742911 Illumination scheme for high-contrast contactless fingerprint images [7429-38]

L. Wang, R. H. Abd El-Maksoud, J. M. Sasian, College of Optical Sciences, The Univ. of Arizona (United States); V. S. Valencia, College of Optical Sciences, The Univ. of Arizona (United States) and Authenti-Corp (United States)

742913 PDV and shock physics: application to nitro methane shock-detonation transition and particles ejection [7429-40]

P. A. Frugier, P. Mercier, J. Bénier, J. Veaux, M. Debruyne, C. Rion, E. Dubreuil, CEA DAM lle de France (France)

742914 Study on the reversibility of the diffraction light path [7429-42]

W. Zhang, L. Wan, Guangxi Univ. (China); Y. Liu, Guangxi Univ. (China) and Bijie College (China); J. Dong, X. Shen, Guangxi Univ. (China)

742915 A novel contactless aliveness-testing (CAT) fingerprint sensor [7429-43]

L. Wang, R. H. Abd El-Maksoud, J. M. Sasian, College of Optical Sciences, The Univ. of Arizona (United States); W. P. Kuhn, Opt-E (United States); K. Gee, Authenti-Corp (United States); V. S. Valencia, College of Optical Sciences, The Univ. of Arizona (United States) and Authenti-Corp (United States)

742916 Optical-fiber vortex-shedding flowmeter based on white-light interference [7429-44] D. Zhao, H. Wu, B. Jia, Fudan Univ. (China); Y. Zhi, Shanghai Institute of Optics and Fine Mechanics (China)

Author Index 


\title{
Conference Committee
}

\author{
Conference Chairs
}

R. John Koshel, Photon Engineering LLC (United States) and College of Optical Sciences, The University of Arizona (United States)

G. Groot Gregory, Optical Research Associates (United States)

Program Track Chair

R. John Koshel, Photon Engineering LLC (United States) and College of Optical Sciences, The University of Arizona (United States)

Program Committee

Dmitry V. Bakin, Micron Technology, Inc. (United States)

W. Andrew Cheng, PROSYS Optics Corporation (United States)

Jyh-Long Chern, National Chiao Tung University (Taiwan)

Oliver Dross, Light Prescriptions Innovators Europe, S. L. (Spain)

Joseph M. Howard, NASA Goddard Space Flight Center (United States)

Richard C. Juergens, Raytheon Missile Systems (United States)

Scott A. Lerner, Hewlett-Packard Co. (United States)

Rongguang Liang, Carestream Health, Inc. (United States)

Paul K. Manhart, IMAGE-N (United States)

Craig Olson, L-3 Communications Sonoma EO (United States)

Andrew Rakich, Large Binocular Telescope Corporation (United States)

Michael D. Robinson, Ricoh Innovations, Inc. (United States)

José Sasián, College of Optical Sciences, The University of Arizona (United States)

David L. Shealy, The University of Alabama at Birmingham

(United States)

Marija Strojnik, Centro de Investigaciones en Óptica, A.C. (Mexico)

Kevin P. Thompson, Optical Research Associates (United States)

Mary G. Turner, Breault Research Organization, Inc. (United States)

\section{Session Chairs}

1 Design in Computed Imaging I

R. John Koshel, Photon Engineering LLC (United States) and College of Optical Sciences, The University of Arizona (United States)

2 Illumination

G. Groot Gregory, Optical Research Associates (United States) 
$3 \quad$ Modeling

Michael D. Robinson, Ricoh Innovations, Inc. (United States)

$4 \quad$ Systems

G. Groot Gregory, Optical Research Associates (United States)

5 Design in Computed Imaging II

Joseph M. Howard, NASA Goddard Space Flight Center (United States)

6 Education

Barbara A. Darnell, ScinTech (United States)

Joseph M. Howard, NASA Goddard Space Flight Center (United States) 


\section{Introduction}

This year in San Diego, California, we held the twelfth conference of Novel Optical Systems Design and Optimization. The conference was well attended and began with a session on Design in Computed Imaging and ended in a joint session with Current Developments in Lens Design and Optical Engineering. This year there were seven oral sessions and one poster session. The primary focus of the conference was the field of optical design for computed imaging sessions. The seven oral sessions had titles of: Design in Computed Imaging I and II, Illumination, Modeling, Systems, Education, and the Invited (joint) Session. These oral sessions covered one-and-a-half days of the entire Optics + Photonics 2009 meeting. Note that the joint session proceedings papers are contained in the Current Developments in Lens Design and Optical Engineering X volume.

The Design in Computed Imaging sessions predominately focused on coding methods to address defocus, depth of field, and image artifacts. The lllumination session presented investigations of lighting, source measurement, and daylighting. The Modeling session tackled new methods of designing imaging optics, while the Systems session looked at the optics in a number of optical systems. The Education session, which may be spun out into its own conference in the near future, looked at optics from the primary to college levels. The joint session had three invited speakers to introduce the audience to new ways that optical design is and can be a factor in our daily lives.

There were a number of invited papers over the duration of the conference:

- A discussion by Tom Vettenburg from Heriot-Watt University (United Kingdom) using phase masks to increase defocus tolerance in digital imaging systems

- A paper given by Dirk Robinson, Guotong Feng, and David Stork about spherically coded imaging to improve lens performance

- Jay Enoch of the University of California, Berkeley gave a paper on the history of imaging optics, showing their use thousands of years ago

- Ken Rockwell presented insights from the non-optical design community on what is practical and what is not

- Yongtian Wang gave a talk about display systems for mixed (i.e., real and virtual concurrently) applications.

As can be seen, the invited topics covered a large breadth of the field of optical design and engineering. It indicates that the optical design community is still working on challenging problems and also that the range of fields calling on optical engineering is increasing. This breadth led to lively and interesting discussions following each paper. Additionally, these discussions were carried into the hallways following each session. In conclusion, the Novel Optical Systems 
Design and Optimization conference continues to build upon previous years. It is expected that next year's conference will maintain this growth.

Our thanks go to those who helped make this conference a success, especially the authors, audience, SPIE staff, and program committee. The authors on their own made this conference an unqualified success. The audience built upon this success by being active and asking engaging questions. The SPIE staff ensured that everything ran smoothly before, during, and after the meeting. The program committee provided excellent assistance to ensure the quality of the content while also presiding over a number of the sessions.

Next year, we will return for the thirteenth iteration of this conference. The chairs will remain for as Groot Gregory and John Koshel. The planning for Novel Optical Systems Design and Optimization XIII in 2010 is already under way, so please start planning submissions, questions, and attendance. Focus themes are being decided at this time. If you would like to assist with the 2010 or later conference, please contact one of us. We look forward to seeing you in 2010 !

\section{R. John Koshel G. Groot Gregory}

